\title{
Correction to: The effect of e/a ratio on thermodynamic parameters and surface morphology of $\mathrm{Cu}-\mathrm{Al}-\mathrm{Fe}-\mathrm{X}$ shape memory alloys
}

\author{
Canan Aksu Canbay ${ }^{1} \cdot \operatorname{Sivar}$ Aziz Baiz ${ }^{1} \cdot$ İskender Özkul ${ }^{2} \cdot$ Aysegül Dere $^{1}$
}

Published online: 9 July 2019

(C) Akadémiai Kiadó, Budapest, Hungary 2019

\section{Correction to: Journal of Thermal Analysis and Calorimetry} https://doi.org/10.1007/s10973-019-08454-8

In the original publication of the article, the second author's family name was incorrectly published. The corrected second author's name is given in this correction.

Publisher's Note Springer Nature remains neutral with regard to jurisdictional claims in published maps and institutional affiliations.

The original article can be found online at https://doi.org/10.1007/s10973-019-08454-8.

Canan Aksu Canbay caksu@ firat.edu.tr

1 Department of Physics, Faculty of Science, Firat University, Elazig, Turkey

2 Mechanical Engineering Department, Engineering Faculty, Mersin University, Mersin, Turkey 